Historic, archived document

Do not assume content reflects current scientific knowledge, policies, or practices. 




\section{THE AUTHORS}

VAL JO ANDERSON is an assistant professor in the Botany and Range Science Department at Brigham Young University in Provo, UT.

ROBERT M. THOMPSON is the Forest range conservationist on the Manti-La Sal National Forest in Price, UT.

\section{ACKNOWLEDGMENTS}

We gratefully acknowledge the technical support of the Shrubland Biology and Restoration Research Work Unit of the Intermountain Research Station. We also express appreciation to K. T. Harper, J. F. Vallentine, S. B. Monsen, L. R. Robison, and L. S. Jeffery for constructive evaluation of an earlier draft of the manuscript. The cover illustration was prepared by Kelly L. Memmott, a wildlife and range student at Brigham Young University, Provo, UT.

\section{RESEARCH SUMMARY}

In the early 1980's, trials to control false hellebore (Veratrum californicum Durand) were initiated on highelevation rangeland in central Utah. Five herbicides (amitrole, picloram, glyphosate, triclopyr, and 2,4-D) and three mechanical treatments (hand cutting, rototilling, and disc chaining) were tested as potential control procedures for treatment of areas infested with false hellebore. Evaluations were conducted at 1, 2, 4, and 9 years after treatment. Stem density of false hellebore treated with herbicides was reduced 40 to 75 percent by the second year after treatment. Following this initial decrease, stem densities increased through the ninth posttreatment year. A single hand cutting appeared to weaken plants the first 2 years after treatment, but baseline stem density increased 45 percent after 9 years. Rototilling, disc chaining, and treatment with picloram providec the most control of stem densities, reducing densities by 87,48 , and 46 percent, respectively. Treatment with picloram appeared to yield the best combination of false hellebore control and community recovery. 


\title{
Chemical and Mechanical Control of False Hellebore (Veratrum californicum) in an Alpine Community
}

\author{
Val Jo Anderson \\ Robert M. Thompson
}

\section{INTRODUCTION}

False hellebore (Veratrum californicum Durand), also known as wild corn, cow cabbage, or veratrum, has not only continued to spread in many high-elevation grassforb meadows, but has invaded some aspen stands in the central Rocky Mountains (Spencer and Thompson 1984). This species has two deleterious effects: (1) it is toxic to livestock, causing abortion in gestating ewes and congenital deformities in surviving lambs (James and others 1980) and (2) the clonal growth and expansion of this species on prime high-elevation sites, in response to overuse of more desirable species in the community, has substantially reduced the potential for natural recovery of desirable species.

While extensive research has been conducted on the toxicity of false hellebore (Binns and others 1963; Keeler 1969, 1990; Keeler and Stuart 1987; Knight 1989), research on false hellebore control is limited to a few herbicide trials completed during the late 1950's and mid-1960's (Klomp 1958; May and others 1968; Street and others 1967, 1968). Williams and Kreps (1970) evaluated 10 herbicides at application rates of between 4 and $12 \mathrm{~kg}$ active ingredient per hectare (ai/ha), reporting 55 to 95 percent control of false hellebore the first year for the four most effective herbicides. This improved to 100 percent control following a second $4-\mathrm{kg}$ ai/ha treatment of the same plots the next year with the amine salt of 2,4-D. Reevaluation of these treatments at 10 years (Williams and Cronin 1981) and 20 years (Williams 1991) indicates long-term control under proper management. Regardless of the herbicide used, the most effective time to apply herbicides for false hellebore control was just after the last leaf expanded, before the flowers began to open (Williams and Kreps 1970).

The high application rates needed for control with 2,4-D and the need for two successive years of application tend to make large-scale treatment economically unattractive. Since these trials in the 1960's, many other herbicides have been developed that have not been evaluated for control of false hellebore.
A study to test alternative herbicides and possible mechanical control methods was initiated by the technical staff of the Manti-La Sal National Forest at the Price Ranger District in the early 1980's. A dense stand of false hellebore was selected to test the following control methods:

$$
\begin{aligned}
& \text { Herbicides: Amitrole, picloram, glyphosate, } \\
& \text { triclopyr, and 2,4-D. } \\
& \text { Mechanical: Hand cutting to ground level, } \\
& \text { rototilling, and disc chaining. }
\end{aligned}
$$

\section{STUDY AREA}

The study area is at the head of Boulger Canyon $(2,896 \mathrm{~m}$ elevation) on the Price Ranger District. The study plots were all located on a north aspect with 5 to 10 percent slope. This area is in a perennial snowdrift site; snow sometimes covers the area until mid-July. Soils are silty clay loams, 38 to $76 \mathrm{~cm}$ deep. The site is grazed seasonally by sheep from July 1 to October 1.

\section{METHODS}

Plots 15 by $15 \mathrm{~m}$ were delimited in a dense patch of false hellebore. Control treatments (except 2,4-D and disc chaining) were applied on August 6, 1982, while plants were growing rapidly and just before their panicles opened. Plant height averaged nearly $91 \mathrm{~cm}$. Temperature at the time of application ranged from 15 to $18^{\circ} \mathrm{C}$, and the air was calm. A backpack sprayer calibrated to deliver $350 \mathrm{~L} / \mathrm{ha}$ of the herbicide and water solution was used for foliar application of amitrole (4 kg ai/ha), glyphosate ( $2 \mathrm{~kg}$ ai/ha), and triclopyr ( $2 \mathrm{~kg}$ ai/ha). Leaf surfaces were thoroughly wetted. Picloram pellets were hand broadcast at the rate of $1 \mathrm{~kg}$ ai/ha. Plants receiving the cutting treatment were cut near the soil surface using a hand sickle. The rototill treatment consisted of one pass of a gasdriven rotary tiller. Soil was tilled to a depth of 10 to $15 \mathrm{~cm}$. False hellebore plant tops, rhizomes, and roots were chopped and mixed into the soil. 
Three other treatments, not part of the initial design, were evaluated as part of this study. Early- and lateseason treatments of 2,4-D ( $2 \mathrm{~kg}$ ai/ha) were initiated using a backpack sprayer as described above. The early-season treatment occurred in June 1981; the late-season treatment occurred in July 1983. These plots were immediately adjacent to the other herbicide plots. No baseline or interim data were collected for these treatments. The disc chaining treatment was completely independent of all preceding treatments and occurred in the drainage immediately west of the Boulger study area in September 1985. A large anchor chain with discs welded to the links was pulled in a loop behind a tracked tractor. A two way chaining across the contour of the slope provided a treatment that knocked down the standing crop and disrupted the rhizome layer of false hellebore. As with the 2,4-D treatments, no pretreatment baseline or interim data were collected for this treatment. For treatments where baseline data were not taken, the baseline was assumed to be 16.8 false hellebore stems per square meter, based on the average baseline population density for the Boulger study treatments.
For data collection, each 15 - by 15-m treatment plot was subdivided into quarters and each quarter was sampled independently. Transect lines were located in the center of the treatment plot and ran the length of each quarter plot. Data were recorded from five $0.25-\mathrm{m}^{2}$ sample quadrats distributed at regular intervals along each transect within each quarter plot. Stem density counts for false hellebore were recorded in 1983,1984 , and 1986. Stem density for false hellebore and nested frequency data for all herbaceous species were recorded in 1991.

Nested frequency data were analyzed for the 16 species encountered often enough to allow comparisons. These data were collected at the same time as the density counts. The $0.25-\mathrm{m}^{2}$ sample quadrat had four divisions of increasing size. A species occurring in the smallest division received a score of 4 , while those occurring first in the other divisions received a score of 3,2 , or 1 , respectively, as the size division increased. No attempt will be made in this report to synthesize conclusions on a species-by-species analysis of the nested frequency data. The data are available in table 1 for treatment-by-treatment and species-byspecies analysis that may be useful for other objectives.

Tabie 1-Nested frequency scores by treatment and species for early 1980's false hellebore treatments in Boulger Canyon. Values preceded by the same letter are not significantly different within a row; values followed by the same letter are not significantly different within a column

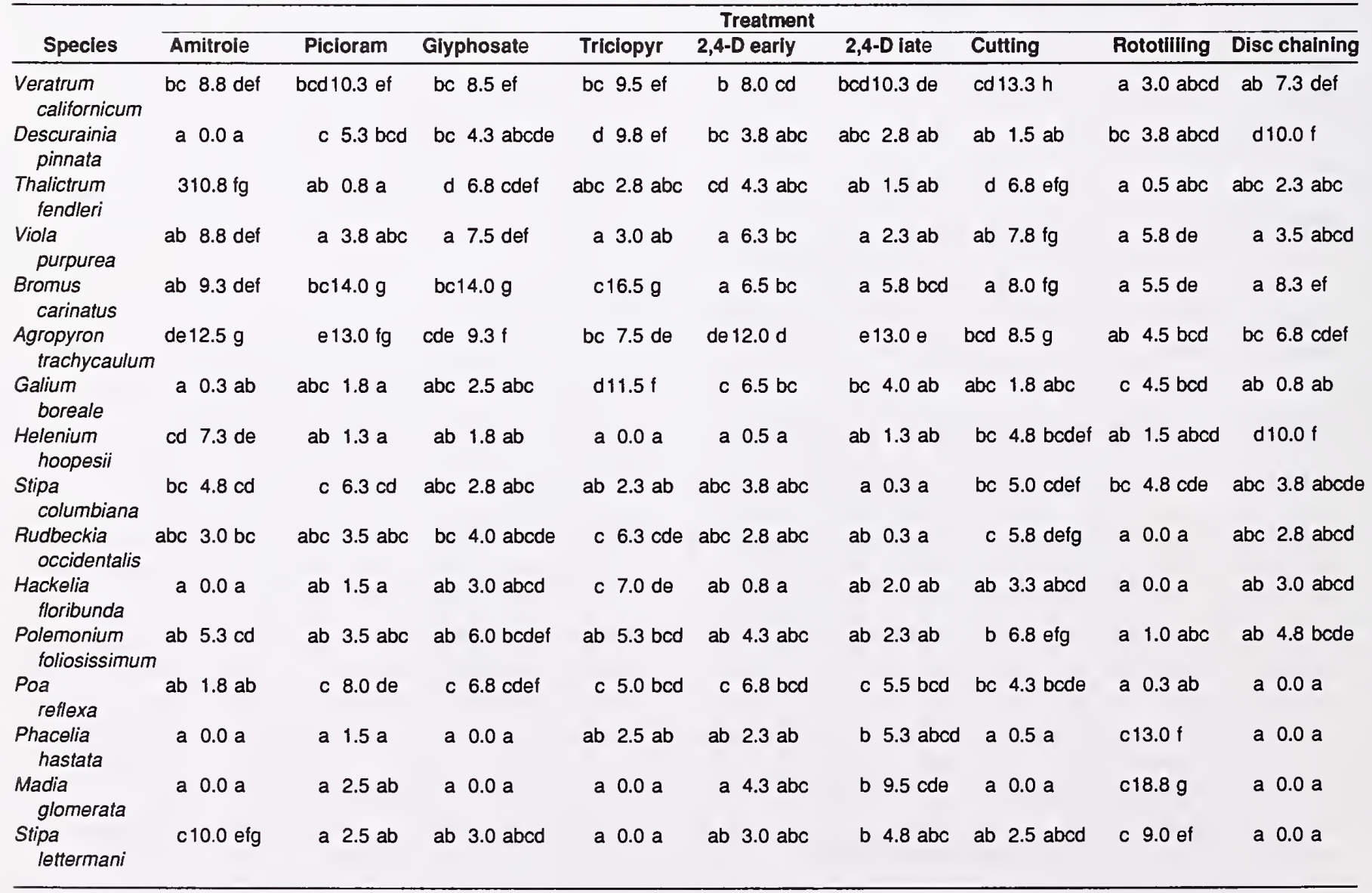


Tabie 2-Species assignment to desirability class based on seral placement and forage potential

\begin{tabular}{lll}
\hline & Desirability class & \\
\hline \multicolumn{1}{c}{ Desirable } & \multicolumn{1}{c}{ Intermediate } & Less desirable \\
\hline Agropyron trachycaulum & Galium boreale & Descurainia pinnata \\
Bromus carinatus & Hackelia floribunda & Helenium hoopesii \\
Poa reflexa & Phacelia hastata & Madia glomerata \\
Stipa columbiana & Polemonium foliosissimum & \\
Thalictrum fendleri & Rudbeckia occidentalis & \\
& Stipa lettermani & \\
& Viola purpurea & \\
\hline
\end{tabular}

Grouping species into classes of plants (desirable, intermediate, and less desirable) and summing their nested frequency scores (cumulative nested frequency) allowed for a more useful analysis determining treatment effects on community structure. Assignment to these classes was based on a combination of species' seral placement and their potential forage utility (table 2). Since community baseline data were not recorded, only differences among treatments may be assessed. This comparison is valid with the assumption that the baseline community was similar throughout the study area.

Standard analysis of variance and Fisher's least significant difference (LSD) mean separation procedures were employed to distinguish treatment differences in stem density and nested frequency scores.

\section{RESULTS}

The level of control achieved by the various chemical and mechanical treatments was quantified only by stem density counts. However, there were noticeable, apparent differences in stem heights and diameters between treatments.

\section{Herbicides}

Amitrole: False hellebore stem density averaged $11.5 / \mathrm{m}^{2}$ before treatment. Stem density was reduced 21.5 percent in 1983,44 percent in 1984,30 percent in 1986, and 32.5 percent in 1991 (fig. 1).

Picloram: False hellebore stem density averaged $16.0 / \mathrm{m}^{2}$ before treatment. Stem density was reduced

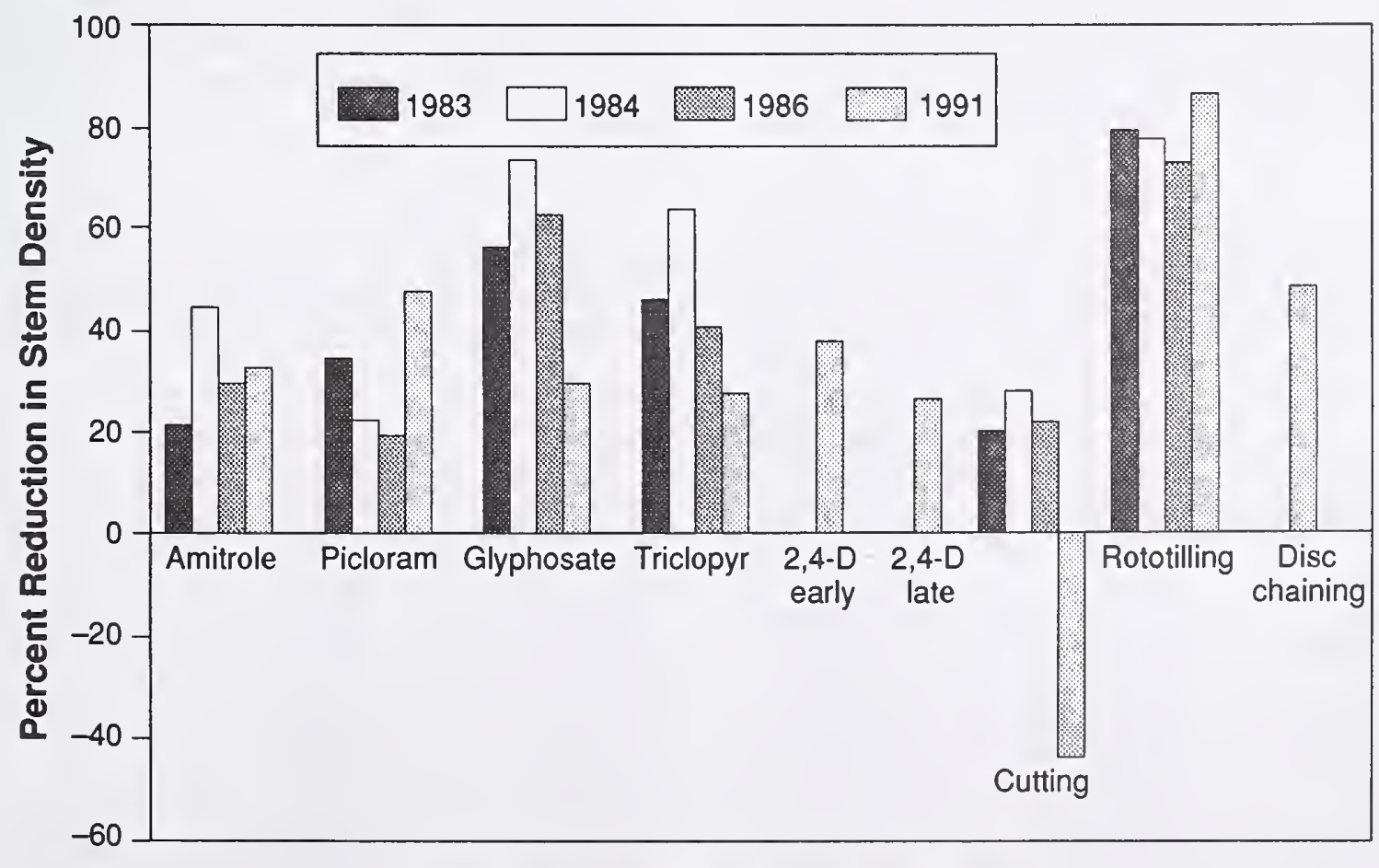

\section{False Hellebore Treatment and Year}

Figure 1-Percent reduction of false hellebore stem density from 1982 to 1983 , 1984,1986 , and 1991 by treatment. 
34.2 percent in $1983,22.1$ percent in $1984,19.5$ percent in 1986, and 46 percent in 1991 (fig. 1).

Glyphosate: False hellebore stem density averaged $14.8 / \mathrm{m}^{2}$ before treatment. Stem density was reduced 55.8 percent in $1983,73.2$ percent in $1984,62.3$ percent in 1986, and 28.5 percent in 1991 (fig. 1).

Triclopyr: False hellebore stem density averaged $22.3 / \mathrm{m}^{2}$ before treatment. Stem density was reduced 45.4 percent in $1983,63.8$ percent in $1984,40.6$ percent in 1986, and 26.0 percent in 1991 (fig. 1).

2,4-D early: The 1991 data indicated a 37 percent reduction in estimated pretreatment false hellebore stem density (fig. 1).

2,4-D late: The 1991 data indicated a 25.5 percent reduction in estimated pretreatment stem density (fig. 1).

\section{Mechanical Treatments}

Hand cutting: False hellebore stem density averaged $14.2 / \mathrm{m}^{2}$ before treatment. Stem density was reduced 19.7 percent in 1983, 27.3 percent in 1984, 21.2 percent in 1986, and increased 43 percent in 1991 (fig. 1). The overall average height of false hellebore plants in this study plot in 1991 was less than that of the initial population. Before treatment, stem heights averaged between 75 and $100 \mathrm{~cm}$; 1 year after treatment, stem heights averaged only 35 to $50 \mathrm{~cm}$. No flowers were produced the year after treatment, but about 50 percent of the plants produced flowers the second year after treatment. Four years after cutting, the average plant height was between 50 and $75 \mathrm{~cm}$ (plants inside the plot were noticeably shorter than those outside).

Rototilling: False hellebore stem density averaged $21.7 / \mathrm{m}^{2}$ before treatment. Stem density was reduced
79.2 percent in $1983,78.2$ percent in $1984,73.3$ percent in 1986, and 87 percent in 1991 (fig. 1).

Disc chaining: The 1991 data indicated a 48 percent reduction in false hellebore pretreatment stem densities as estimated from composite baseline stem density (fig. 1).

By 1991 all treatments were statistically more effective than the hand cutting, the herbicides were not significantly different from each other, and the rototilling was significantly more effective than all other treatments except for disc chaining and picloram $(p<0.001)$.

\section{Community Response Based on Nested Frequency and Species Richness}

For the majority of the treatments (2,4-D early, 2,4-D late, amitrole, triclopyr, glyphosate, and hand cutting) the community response was similar. The pattern seemed to be a high score for desirable species, an intermediate to high score for intermediate species, and a low score for less desirable species (table 3; fig. 2). The picloram treatment had the highest score for desirable species and low scores for intermediate and less desirable species. The rototill treatment had a low score for desirable species, a relatively high score for intermediate species, and an intermediate score for less desirable species. The disc chain treatment had an intermediate score for desirable species, a low score for intermediate species, and an intermediate score for less desirable species.

Species richness (number of species occurring in the treatment) was lowest in the 2,4-D and rototill treatments and highest in the triclopyr treatment (table 3).

Table 3-Cumulative nested frequency scores, stem density reduction, and species richness for the early 1980's false hellebore treatments in Boulger Canyon. Values preceded by the same letter are not significantly different within a row; values followed by the same letter are not significantly different within a column

\begin{tabular}{|c|c|c|c|c|c|}
\hline \multirow[b]{2}{*}{ Treatment } & \multicolumn{3}{|c|}{$\begin{array}{l}\text { Cumulative nested frequency scores } \\
\text { for recovered community }\end{array}$} & \multirow[b]{2}{*}{$\begin{array}{l}\text { Percent stem } \\
\text { reduction }\end{array}$} & \multirow[b]{2}{*}{$\begin{array}{l}\text { Species } \\
\text { richness }\end{array}$} \\
\hline & Desirable & Intermediate & $\begin{array}{l}\text { Less } \\
\text { desirable }\end{array}$ & & \\
\hline Amitrole & a $38.0 \mathrm{c}$ & $a b 24.3 \mathrm{bcd}$ & b 10.3 a & $32.5 \mathrm{~b}$ & $15.8 \mathrm{abc}$ \\
\hline Picloram & a $42.0 \mathrm{c}$ & b $14.5 \mathrm{ab}$ & b 12.5 a & $46.0 \mathrm{bc}$ & $15.0 \mathrm{abc}$ \\
\hline Glyphosate & a $39.5 \mathrm{c}$ & b $22.0 \mathrm{bc}$ & b $10.0 \mathrm{a}$ & $28.5 b$ & $14.3 \mathrm{abc}$ \\
\hline Triclopyr & a $34.0 \mathrm{bc}$ & a $29.3 \mathrm{~cd}$ & b 16.0 ab & $26.0 \mathrm{~b}$ & $17.0 \mathrm{c}$ \\
\hline 2,4-D early & a $33.3 \mathrm{bc}$ & b 23.0 bc & c $11.3 \mathrm{a}$ & $37.0 \mathrm{~b}$ & $14.0 \mathrm{ab}$ \\
\hline 2,4-D late & a $26.0 \mathrm{ab}$ & $a b 20.5 a b c$ & b $13.3 \mathrm{a}$ & $25.5 b$ & $13.0 \mathrm{a}$ \\
\hline Cutting & a 32.5 bc & $a b 22.5 b c$ & b $12.0 \mathrm{a}$ & $-43.0 a$ & $16.0 \mathrm{bc}$ \\
\hline Rototilling & a 15.5 a & b $33.3 \mathrm{~d}$ & ab $24.0 \mathrm{c}$ & $87.0 \mathrm{C}$ & $13.0 \mathrm{a}$ \\
\hline Disc chaining & a 21.0 a & a $12.0 \mathrm{a}$ & a 22.8 bc & $48.0 \mathrm{bc}$ & $15.8 \mathrm{abc}$ \\
\hline
\end{tabular}




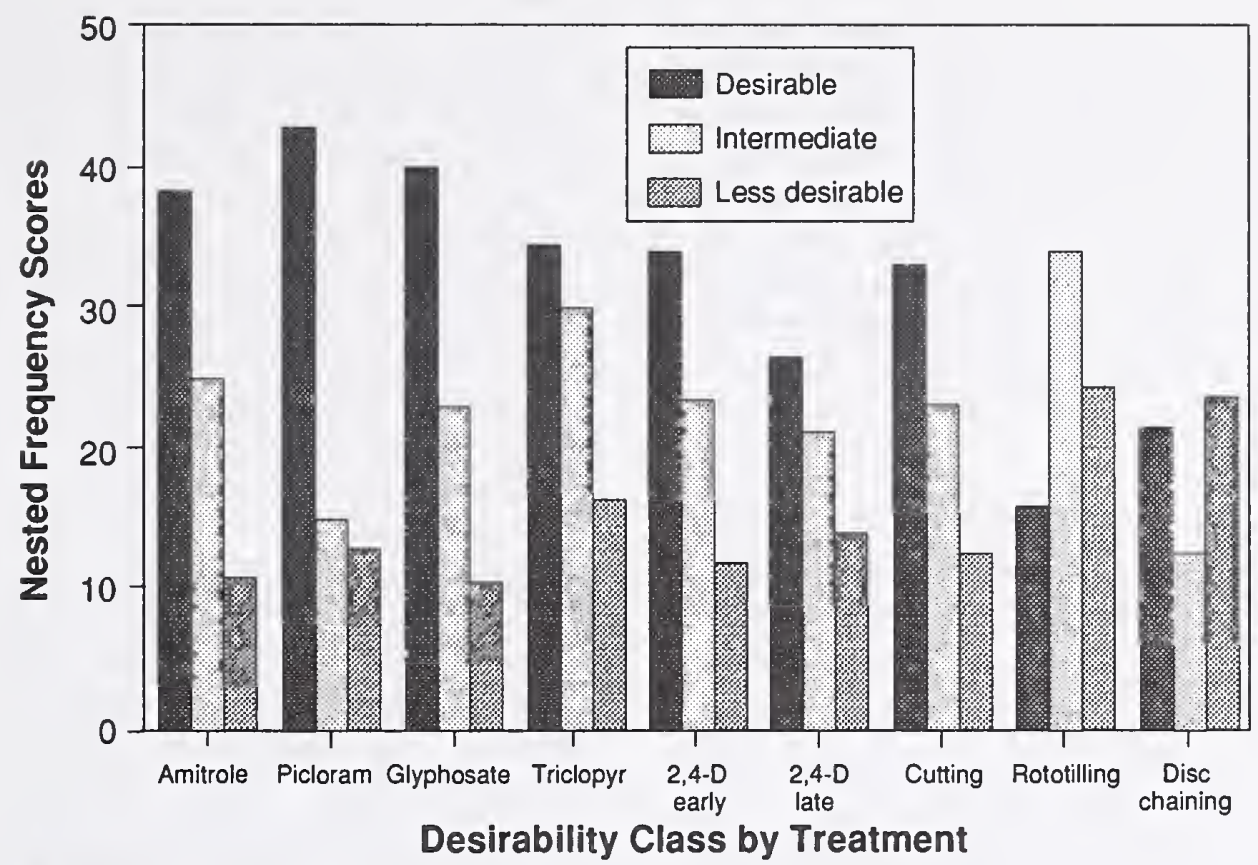

Figure 2-Community response after 9 years to control treatments for false hellebore by desirability class.

\section{DISCUSSION}

These data suggest that rototilling produced the most immediate and sustainable reduction of false hellebore. A possible disadvantage is that rototilling is limited to areas accessible by a tractor and to areas with a limited amount of rock in the top $20 \mathrm{~cm}$ of the soil profile. In addition, some form of reseeding will be required afterward, since the weedy vegetation that becomes established otherwise is little better than the initial false hellebore patch. Tarweed (Madia glomerata) was the dominant replacement species after this treatment. The disc chaining treatment produced a similar response; false hellebore stem density was reduced substantially, but the species replacing it were often undesirable.

The control achieved by herbicides appeared to be greatest within the first 2 posttreatment years, declining afterward. All of the herbicide treatments would likely have been enhanced by reseeding. A vigorous reseeding would probably suppress the recovering false hellebore stand and improve the composition of the posttreatment plant community. The results from this study indicated no significant differences between the degree of control achieved by the different herbicides $(\alpha=0.05)$; however, the picloram treatment reduced stem density the most after 9 years. Posttreatment community structure was also similar among these treatments with a large majority of the species being classified as having either desirable or intermediate qualities.
The cutting treatment did not appreciably control the stem density of false hellebore, although a reduction in canopy height and plant vigor was observed during the first years following treatment. A followup defoliation treatment may have killed these plants, which were already under apparent stress from the first treatment. The treatment appeared to have stimulated stem production by 1991 ; hand cutting was the only treatment that produced higher stem densities in 1991 than existed before treatment.

The lack of true replication in this study precludes definitive conclusions from being drawn; nor can specific applications be recommended for a variety of sites. However, because data relating to control of false hellebore are so limited, managers have little information on which to base management decisions. Data from this study may provide useful information for control efforts. The nearly 10-year data base helps evaluate treatment longevity. Further work in this area is necessary to provide a better understanding of control options.

\section{CONCLUSIONS}

Final selection of a control methodology should be made after carefully analyzing the costs of each treatment and the potential for recovery of the native community. Where logistically and financially feasible, rototilling or some other treatment that disrupts false hellebore's rhizome would appear to be the best alternative for control; however, after such a disturbance 
these sites would have to be reseeded to protect against the invasion of other undesirable, weedy plants. Glyphosate treatments appeared to result in the best initial control among the herbicide treatments. Reseeding might greatly improve the longevity and success of this treatment. Considering herbicide application without reseeding, the picloram treatment appears to have had the best control over the full 9-year period and the most favorable community response.

\section{REFERENCES}

Binns, W.; James, L. F.; Shupe, J. L.; Everett, G. 1963. A congenital cyclopain-type malformation in lambs induced by maternal ingestion of a range plant, Veratrum californicum. American Journal of Veterinary Research. 24: 1164-1175.

James, L. F.; Keeler, R. F.; Johnson, A. E.; Williams, M. C.; Cronin, E. H.; Olsen, J. D. 1980. Plants poisonous to livestock in the Western States. Logan, UT: U.S. Department of Agriculture, Agricultural Research Service, Poisonous Plants Laboratory. 90 p.

Keeler, R. F. 1969. Teratogenic compounds of Veratrum californicum (Durand)-VI. The structure of cyclopamine. Phytochemistry. 8: 223-225.

Keeler, R. F. 1990. Early embryonic death in lambs induced by Veratrum californicum. Cornell Veterinarian. 80: 203-207.

Keeler, R. F.; Stuart, L. D. 1987. The nature of congenital limb defects induced in lambs by maternal ingestion of Veratrum californicum. Journal of Toxicology: Clinical Toxicology. 25: 273-286.
Klomp, G. J. 1958. California false hellebore (Veratrum californicum) and cinquefoil (Potentilla spp.) and their control by 2,4-D and ATA. Research Progress Report. Logan, UT: The Western Society of Weed Science. $35 \mathrm{p}$.

Knight, A. P. 1989. Veratrum californicum poisoning. Compendium on Continuing Education for the Practicing Veterinarian. 11: 528-531.

May, J. W.; Hepworth, H. M.; Fults, J. L. 1968. A test of picloram and dicamba for control of certain range weeds in northwestern Colorado. Research Progress Report. Logan, UT: The Western Society of Weed Science: 27-28.

Spencer, Steven M.; Thompson, Robert M. 1984. Control of Veratrum californicum on the Manti-La Sal National Forest. Unpublished report on file at: Manti-La Sal National Forest, Price, UT.

Street, J. E.; Bayer, D. E.; Brooks, W. H. 1967. Control of western false hellebore (Veratrum californicum Durand). Research Progress Report. Logan, UT: The Western Society of Weed Science: 10-11.

Street, J. E.; Bayer, D. E.; Brooks, W. H. 1968. Control of false hellebore (Veratrum californicum Durand). Research Progress Report. Logan, UT: The Western Society of Weed Science: 14-15.

Williams, M. C. 1991. Twenty-year control of California false-hellebore. Weed Technology. 5: 40-42.

Williams, M. C.; Kreps, L. B. 1970. Chemical control of western false hellebore. Weed Science. 18: 481-483.

Williams, M. C.; Cronin, E. H. 1981. Ten-year control of western false hellebore (Veratrum californicum). Weed Science. 29: 22-23. 


Anderson, Val Jo; Thompson, Robert M. 1993. Chemical and mechanical control of false hellebore (Veratrum californicum) in an alpine community. Res. Pap. INT-469. Ogden, UT: U.S. Department of Agriculture, Forest Service, Intermountain Research Station. 6 p.

Herbicide and mechanical control treatments for false hellebore (Veratrum californicum Durand) were applied in the early 1980's at an alpine site in central Utah. Periodic data collection through 1991 indicated the treatments' relative effectiveness. The 1991 data also evaluated natural recovery of the understory plant community. Mechanical treatments were most effective when the rhizome was disrupted; however, the ensuing plant communities had a high density of weeds. Several herbicides also effectively controlled false hellebore, with fewer weeds in the understory afterward.

KEYWORDS: herbicides, weed control, mechanical methods, hand cutting, rotary cultivators, disc chaining

\section{PESTICIDE PRECAUTIONARY STATEMENT}

This publication reports research involving pesticides. It does not contain recommendations for their use, nor does it imply that the uses discussed here have been registered. All uses of pesticides must be registered by appropriate State and/or Federal agencies before they can be recommended.

CAUTION: Pesticides can be injurious to humans, domestic animals, desirable plants, and fish or other wildlife- if they are not handled or applied properly. Use all pesticides selectively and carefully. Follow recommended practices for the disposal of surplus pesticides and pesticide containers.

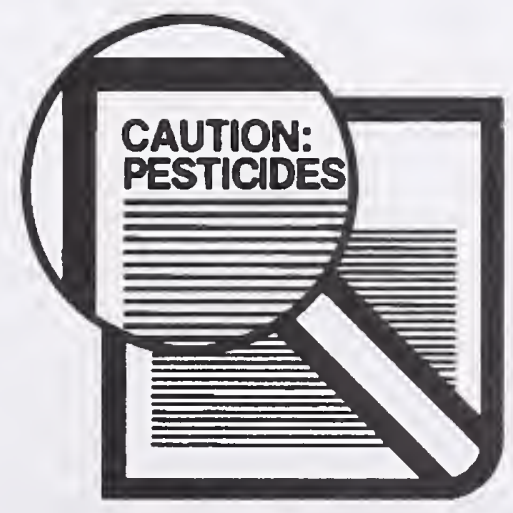




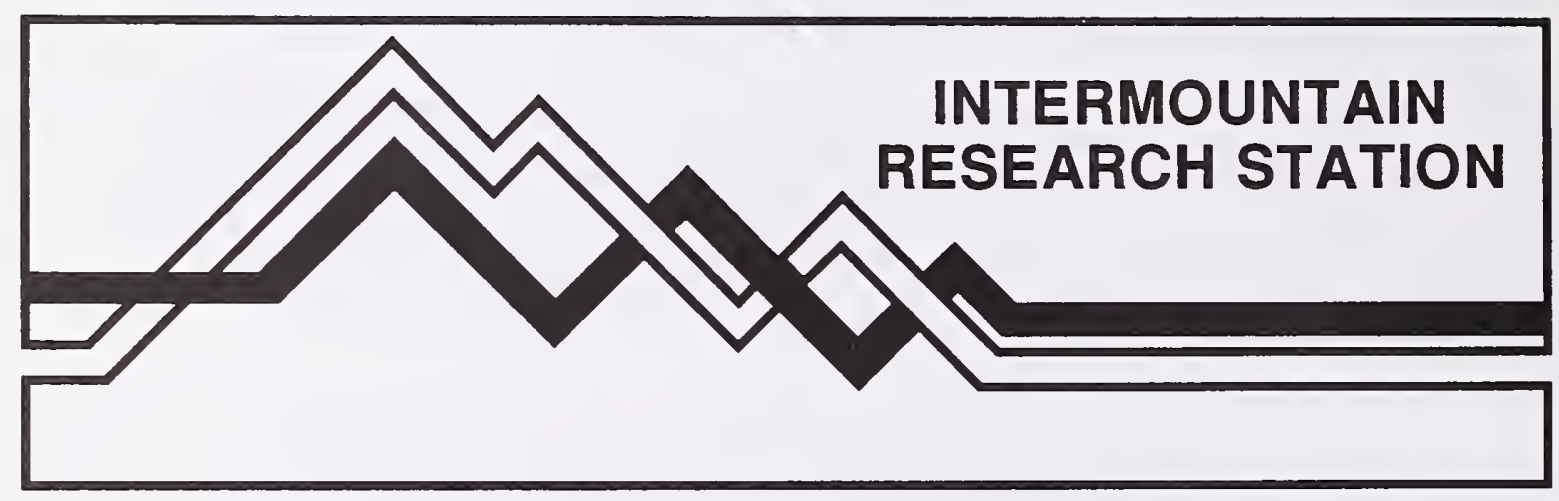

The Intermountain Research Station provides scientific knowledge and technology to improve management, protection, and use of the forests and rangelands of the Intermountain West. Research is designed to meet the needs of National Forest managers, Federal and State agencies, industry, academic institutions, public and private organizations, and individuals. Results of research are made available through publications, symposia, workshops, training sessions, and personal contacts.

The Intermountain Research Station territory includes Montana, Idaho, Utah, Nevada, and western Wyoming. Eighty-five percent of the lands in the Station area, about 231 million acres, are classified as forest or rangeland. They include grasslands, deserts, shrublands, alpine areas, and forests. They provide fiber for forest industries, minerals and fossil fuels for energy and industrial development, water for domestic and industrial consumption, forage for livestock and wildlife, and recreation opportunities for millions of visitors.

Several Station units conduct research in additional western States, or have missions that are national or international in scope.

Station laboratories are located in:

Boise, Idaho

Bozeman, Montana (in cooperation with Montana State University)

Logan, Utah (in cooperation with Utah State University)

Missoula, Montana (in cooperation with the University of Montana)

Moscow, Idaho (in cooperation with the University of Idaho)

Ogden, Utah

Provo, Utah (in cooperation with Brigham Young University)

Reno, Nevada (in cooperation with the University of Nevada)

The policy of the United States Department of Agriculture Forest Service prohibits discrimination on the basis of race, color, national origin, age, religion, sex, or disability, familial status, or political affiliation. Persons believing they have been discriminated against in any Forest Service related activity should write to: Chief, Forest Service, USDA, P.O. Box 96090, Washington, DC 20090-6090. 